\title{
ARCHIVES OF CONJURE
}

GENDER, THEORY, AND RELIGION 


\section{GENDER, THEORY, AND RELIGION}

\section{AMY HOLLYWOOD, EDITOR}

The Gender, Theory, and Religion series provides a forum for interdisciplinary scholarship at the intersection of the study of gender, sexuality, and religion.

Martyrdom and Memory: Early Christian Culture Making,

Elizabeth A. Castelli

When Heroes Love: The Ambiguity of Eros in the Stories of Gilgamesh and David, Susan Ackerman

Abandoned to Lust: Sexual Slander and Ancient Christianity, Jennifer Wright Knust

Bodily Citations: Religion and Judith Butler, Ellen T. Armour and Susan M. St. Ville, editors

Naming the Witch: Magic, Ideology, and Stereotype in the Ancient World, Kimberly B. Stratton

Dying to Be Men: Gender and Language in Early Christian Martyr Texts, L. Stephanie Cobb

Tracing the Sign of the Cross: Sexuality, Mourning, and the Future of American Catholicism, Marian Ronan

Between a Man and a Woman? Why Conservatives Oppose Same-Sex Marriage, Ludger H. Viefhues-Bailey

Promised Bodies: Time, Language, and Corporeality in Medieval Women's Mystical Texts, Patricia Dailey

Christ Without Adam: Subjectivity and Difference in the Philosophers' Paul, Benjamin H. Dunning

Electric Santería: Racial and Sexual Assemblages of Transnational Religion, Aisha M. Beliso-De Jesús

Acute Melancholia and Other Essays: Mysticism, History, and the Study of Religion, Amy Hollywood 


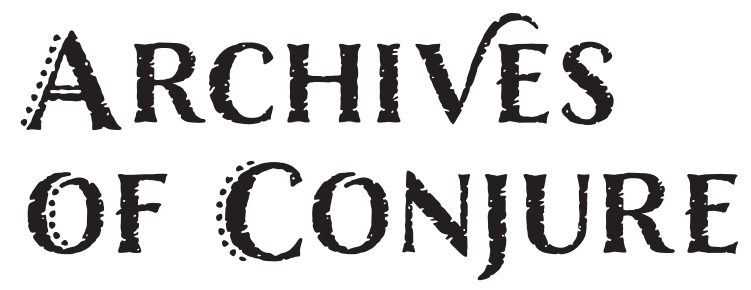

ㅂ...

STORIES OF

THE DEAD IN

AFrOLATINX

CULTURes

aro.t.e.

SOLIMAR OTERO

Columbia University Press / New York 
Columbia University Press

Publishers Since 1893

New York Chichester, West Sussex

cup.columbia.edu

Copyright (C) 2020 Columbia University Press

All rights reserved

This book was made possible by financial assistance from the RUTH LANDES MEMORIAL RESEARCH FUND, a program of the Reed Foundation.

Library of Congress Cataloging-in-Publication Data

Names: Otero, Solimar, author.

Title: Archives of conjure : stories of the dead in Afrolatinx cultures / Solimar Otero.

Description: New York : Columbia University Press, [2020] | Series: Gender, theory, and religion | Includes bibliographical references and index.

Identifiers: LCCN 201903865I (print) | LCCN 2019038652 (ebook) | ISBN 978023II94327 (cloth) | ISBN 978023II94334 (trade paperback) | ISBN 9780231550765 (ebook)

Subjects: LCSH: Spiritualism—Caribbean Area. | Afro-Caribbean cults. | Blacks-Caribbean Area-Religious life. | BlacksCaribbean Area-Rites and ceremonies. | Spirits. | Women and spiritualism-Caribbean Area. | Material culture-Religious aspects. | Water-Religious aspects. | Caribbean Area—Religious life and customs.

Classification: LCC BFI242. $\mathrm{C}_{37} \mathrm{O}_{4} 2 \mathrm{O} 20$ (print) | LCC BFI242. $\mathrm{C}_{37}$ (ebook) | DDC 133.909729 - dc23

LC record available at https://lccn.loc.gov/201903865I

LC ebook record available at https://1ccn.loc.gov/2019038652

Columbia University Press books are printed on permanent and durable acid-free paper.

Printed in the United States of America

Cover image: (C) Martin Tsang, Collares de Mazo for the Deities Erinle and Olokun.

Cover design: Lisa Hamm 
Dedicated to the spirit of José Días Casada, dear friend and teacher, iba $e$.

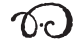



Si la Luz redentora te llama

Y te llama con amor a la tierra

Yo quisiera ver a ese ser

Cantándole gloria al divino Manuel

Oye buen ser

Avanza y ven

Que el coro te llama

Y te dice, "ven."

-Traditional Afro-Cuban spirit mediums'song 
